\title{
NOVEL KLEBSIELLA PNEUMONIAE VIRULENT BACTERIOPHAGE KPPK108.1 CAPABLE OF INFECTING THE K108 SEROTYPE STRAINS
}

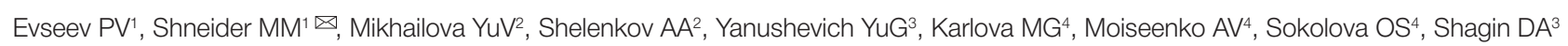

Shemyakin-Ovchinnikov Institute of Bioorganic Chemistry, Moscow, Russia

${ }^{2}$ Central Research Institute of Epidemiology of Rospotrebnadzor, Moscow, Russia

${ }^{3}$ Pirogov Russian National Research Medical University, Moscow, Russia

${ }^{4}$ Lomonosov Moscow State University, Moscow, Russia

Multidrug-resistant Klebsiella pneumoniae strains are one of the major causes of nosocomial infections caused by the antibiotic-resistant bacteria. There are different options for dealing with this threat, among which is the clinical application of bacteriophages. The study was aimed to isolate and describe a virulent bactriophage, having the potential for therapeutic use. The standard phage biology and bioinformatic methods were used, which included the advanced techniques for protein structure prediction (AlphaFold software), and electron microscopy. The virulent podovirus KPPK108.1, being the member of genus Drulisvirus, which is able to specifically infect the K. pneumoniae strains with the KL108 type capsular polysaccharide, has been isolated from the wastewater. The sequence of the bactriophage genome has been defined, the biological properties have been investigated, and the genetic features have been described.

Keywords: bacteriophage, Klebsiella pneumoniae, capsular polysaccharide, depolymerase

Funding: the study was funded by the Ministry of Health of the Russian Federation (EGISU R\&D № 121052800048-3).

Acknowledgements: the authors wish to thank the Center for Precision Genome Editing and Genetic Technologies for Biomedicine, Pirogov Russian National Research Medical University, for advice on research methods.

Author contribution: Shagin DA - research conceptualization, study management, manuscript writing; Evseev PV, Shelenkov AA — formal analysis of sequencing data, manuscript editing; Shneider MM — methodology, study management; Mikhailova YuV — sequencing, data validation; Yanushevich YuG, Moiseenko AV, Karlova MG — methodology; Sokolova OS — electron microscopy, methodology.

$\varangle$ Correspondence should be addressed: Mikhail M. Shneider Miklukho-Maklaya, 16/10, Moscow, 117997, Russia; mm_shn@mail.ru

Received: 08.12.2021 Accepted: 22.12.2021 Published online: 30.12.2021

DOI: $10.24075 /$ brsmu.2021.068

\section{НОВЫЙ ВИРУЛЕНТНЫЙ БАКТЕРИОФАГ КLEВSIELLA PNEUMONIAE KPPK108.1, ИНФИЦИРУЮЩИЙ ШТАММЫ СЕРОТИПА К108}

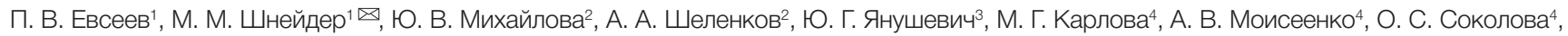
Д. А. Шагин ${ }^{3}$

${ }^{1}$ Институт биохимии имени М. М. Шемякина и Ю. А. Овчинникова, Москва, Россия

2 Центральный научно-исследовательский институт эпидемиологии Роспотребнадзора, Москва, Россия

${ }^{3}$ Российский национальный исследовательский медицинский университет имени Н. И. Пирогова, Москва, Россия

${ }^{4}$ Московский государственный университет имени М. В. Ломоносова, Москва, Россия

Мультирезистентные штаммы Klebsiella pneumoniae являются одной из самых серьезных причин внутрибольничных инсекций, вызванных бактериями, устойчивыми к антибиотикам. Существуют различные варианты борьбы с этой угрозой, один из них - клиническое использование бактериофагов. Целью работы было выделить и детально охарактеризовать вирулентный бактриофаг, имеющий потенциал для терапевтического применения. Использовали стандартные методы фаговой биологии, биоинформатики, включая современные способы предсказания белковых структур (программа AlphaFold), электронную микроскопию. Из образцов сточных вод был выделен вирулентный подовирус KPPK108.1, относящийся к роду Drulisvirus, специфично инфицирующий штаммы K. pneumoniae, имеющие капсулярный полисахарид типа KL108, определена последовательность его генома, исследованы его биологические свойства и дана генетическая характеристика.

Ключевые слова: бактериофаг, Klebsiella pneumoniae, капсулярный полисахарид, деполимераза

Финансирование: работа выполнена при финансовой поддержке Министерства здравоохранения Российской Федерации (ЕГИСУ НИОКТР № 121052800048-3).

Благодарности: авторы благодарят Центр высокоточного редактирования и генетических технологий для биомедицины РНИМУ им. Н. И. Пирогова за консультации по методической части исследования.

Вклад авторов: Д. А. Шагин — концептуализация, руководство исследованием, редактирование рукописи; П. В. Евсеев, А. А. Шеленков - формальный анализ данных секвенирования, редактирование рукописи; М. М. Шнейдер - методология, руководство исследованием; Ю. В. Михайлова секвенирование, валидация данных; Ю. Г. Янушевич, А. Моисеенко, М. Г. Карлова - методология; О. С. Соколова - электронная микроскопия, методология.

$\triangle$ Для корреспонденции: Михаил Маркович Шнейдер ул. Миклухо-Маклая, д. 16/10, г. Москва, 117997, Россия; mm_shn@mail.ru

Статья получена: 08.12.2021 Статья принята к печати: 22.12.2021 Опубликована онлайн: 30.12.2021

DOI: $10.24075 /$ vrgmu.2021.068

The modern personalized approach to phage therapy is based on the detailed assessment of the interaction between phages and bacterial cells. Bacterial carbohydrates exposed on the cell surface, O-antigens and capsular polysaccharides, are one of the most important specificity determinants in the phage-cell interaction. Capsular polysaccharides of K. pneumoniae, being the virulence factors [1], are highly diverse in their structure. Currently, bioinformatics databases indicate the existence of at least 134 genetic variants [2]. To meet the challenges of clinical practice it is necessary to create the collection of phages with 
the defined specificity, inter alia based on their capacity of adsorption through recognition of capsular polysaccharides with certain structure. The study was aimed to isolate the virulent phage, which specifically infected the previously described K. pneumoniae strains with the KL108 capsular polysaccharide, as well as to fully explore the biological and genetic features of the phage. Standard phage biology methods, electron microscopy, and bioinformatics, including the advanced methods for protein structure prediction (AlphaFold software) were used in order to provide the comprehensive description of the phage.

\section{METHODS}

The P224 (1732) and P225 (1333) clinical strains of K. pneumoniae with the K108 type capsular polysaccharide were obtained from the collection of the Institute of Epidemiology (Moscow, Russia). The wastewater samples, collected from the wastewater treatment facilities in Moscow, were used for bacteriophage isolation. Dry components of the bacterial culture medium (trypton, $10 \mathrm{~g} / \mathrm{L}$, yeast extract, $5 \mathrm{~g} / \mathrm{L}, \mathrm{NaCl}$, $5 \mathrm{~g} / \mathrm{L})$ were added to the wastewater samples previously clarified by centrifugation, then the media were inoculated with the bacterial cells culture being in the phase of exponentia growth. Cultivation was carried out at $37^{\circ} \mathrm{C}$ for $16 \mathrm{~h}$. The bacterial culture was subsequently inactivated with chloroform, and the samples were clarified by centrifugation. Phages were detected by titration using the double-layer agar plate method. The isolated phage was titrated twice in a row in order to obtain single phage plaques. Preparative bacteriophage growth was performed in $1 \mathrm{~L}$ of the $\mathrm{P} 224$ strain culture at $37^{\circ} \mathrm{C}$. Bacteriophage was precipitated with polyethylene glycol and purified by caesium chloride density gradient ultracentrifugation [3].

Genomic DNA of the phage was extracted from the purified phage preparation by incubation with the solution, containing 100 mM Tris- $\mathrm{HCl}$ (pH 7.5), 25 mM EDTA, $1.5 \mathrm{M} \mathrm{NaCl}, 2 \%(\mathrm{w} / \mathrm{v})$ CTAB buffer, $0.3 \%(\mathrm{v} / \mathrm{v}) \beta$ - mercaptoethanol, and $50 \mathrm{mg} / \mathrm{mL}$ of proteinase $\mathrm{K}$, at $50{ }^{\circ} \mathrm{C}$ for $30 \mathrm{~min}$, with subsequent chloroform DNA extraction, and precipitated by adding 0.6 volume of isopropyl alcohol. Genome sequencing was performed on the MiSeq platform using the Nextera DNA library preparation kit (Illumina; USA). A single contig was assembled from the resulting sequences using v. 3.13 of the SPAdes software [4].

The experiment aimed at assessing the phage particle production was performed in accordance with the previously reported protocol [5].

Negative contrast electron microscopy was utilized to visualize the phage particles. Phage preparation with a volume of $3 \mu \mathrm{L}$ was applied to a carbon-coated 400 mesh grid. The negatively contrasted preparation was obtained by $1 \%$ uranyl acetate staining for $30 \mathrm{~s}$. Imaging was performed with the JEOL JEM-2100 $200 \mathrm{kV}$ transmission electron microscope (JEOL USA Inc.; USA) at 30,000x magnification.

The Klebsiella bacteriophage KPPK108.1 was annotated with the Prokka tool [6] using the embedded databases. The functions of the genome protein products were predicted with the BLAST search tool [7] based on the known homologs, and by the HMM-HMM comparison, performed with the Hhpred [8] and Phyre2 [9] web-based tools using the SCOPe70_2.07, ECOD_ECOD_F70, and UniProt-SwissProt-viral70 databases. $E$ value $<10^{-5}$ was used as a criterion of significant similarity in BLAST analysis; the Phyre2 "confidence" and HHpred "probability" values exceeding 95\% were used as the criteria of significant similarity for the HMM-HMM comparison. Genetic mapping was carried out with the Geneious Prime software [10].
Genome sequences of bacteriophages to be used for comparison with the KPPK108.1 phage were downloaded from the NCBI Genome database [11]. The average nucleotide identity was calculated using the VIRIDIC online service [12] and the orthoANlu software [13]. Phylogenetic analysis was performed by the maximum likelihood method implemented in the RaxML program [14] with the use of the GAMMA LG amino acid substitution model [15] and the concatenated amino acid sequence alignment of the major capsid protein, terminase large subunit, DNA polymerase, and RNA polymerase. The sequences were aligned with the MAFFT program [16] and concatenated with the Geneious Prime software [10]. The intergenomic comparison diagram was created with the Easyfig application [17] using the TBLASTX tool [7] to find the homologous regions within genomes.

The models of the gene 8 product tertiary structure and the tailspike protein quaternary structure for the Klebsiella bacteriophage KPPK108.1 were constructed with the AlphaFold-Multimer application [18, 19]. The tailspike protein structure of the Enterobacteria phage -92 was dowloaded from the PDB database [20]. Electrostatic surface charge of the tailspike protein was calculated using the APBS program [21]. The UCSF Chimera program was used for structure alignment and visualization [22].

\section{RESULTS}

The KPPK108.1 bacteriophage forms clear plaques, $5 \mathrm{~mm}$ in diameter, surrounded by the translucent halos, in the bacterial cultures grown on the agar plates (Fig. 1). The presence of a halo typically indicate the presence of phage-derived depolymerase, which has been confirmed by further research. The one-step growth curve showed a latent period of 15 min and burst size of 46 phage particles per one infected cell.

Klebsiella bacteriophage KPPK108.1 has a genome, typical for the Autographiviridae phages, which consists of double-stranded DNA 43,755 bp in length with the direct terminal repeats $244 \mathrm{bp}$ in size. The GC-content is $53.6 \%$, somewhat lower than the value of $57.5 \%$, characteristic of the sequenced K. pneumoniae strain HS11286 (GenBank Accession

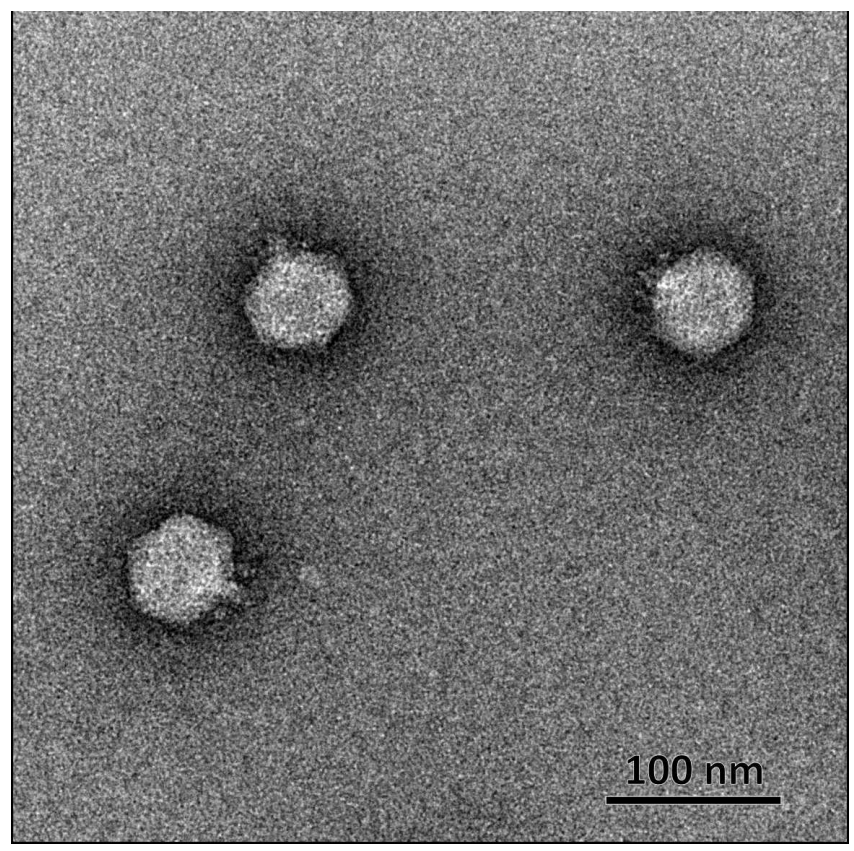

Fig. 1. Electron microscopy of Klebsiella bacteriophage KPPK108.1. Negative staining with $1 \%$ uranyl acetate, magnification $\times 30,000$ 
CP003200.1). The search for coding sequences revealed a total of 56 protein-coding genes and no tRNA-encoding genes in the genome (Fig. 2). The search for homologous and similar sequences using the BLAST algorithm and the HMMHMM comparison in public databases and web servers made it possible to predict the functions of 29 proteins, encoded in the genome. It was not possible to identify the functions of 27 proteins. No genes, encoding integrases or other proteins specific to temperate phages, were found in the genome.

Comparison of the average nucleotide identity (ANI), involving all 14,923 genes of tailed bacteriophages, deposited in the NCBI Genome database, revealed a group of Klebsiella bacteriophages of the genus Drulisvirus, being the most close to phage KPPK108.1 based on this parameter (Fig . 3). The ANI values of phage KPPK108.1 and a typical phage of the genus Drulisvirus, Klebsiella phage KP34, are 73.0\%. Phylogenetic analysis, performed with the use of the concatenated amino acid sequences of the major capsid protein, large terminase subunit, DNA polymerase, and RNA polymerase, shows that Drulisvirus bacteriophages and KPPK108.1 phage form a monophyletic group (Fig. 4). The genetic makeup and genomic organization of the phage KPPK108.1 are generally similar to those of the other Autographiviridae phages (Fig. 5), and are almost identical to those of other members of the genus Drulisvirus. An interesting feature of the gene 8 product was found. Protein structural modeling revealed unusual L-shape of the protein with a tubular C-terminal region (Fig. 6.1). This region was characterized by the number of positively charged amino acid residues above the average. Electrostatic field simulation showed that the $\mathrm{C}$-terminal region of the gene 8 product had a significant negative surface charge (up to -5) (Fig. 6.2).

Bioinformatic analysis of the KPPK108.1 phage genome revealed genes, encoding the head-tail connector and tailspike proteins. Modeling and analysis of the tailspike protein structure was performed (Fig. 6). The search for similar structures revealed a high degree of similarity between the tailspike of the phage KPPK108.1 and the tailspike of the Enterobacteria phage -92 (PDB entry 6EOV) (Fig. 6) exhibiting colanidase activity confirmed by experimental data [23].

\section{DISCUSSION}

The genome-wide similarity score of the phages KPPK108.1 and KP34 exceeding $70 \%$ of the genus boundary, together with the results of the phylogenetic analysis performed based on the concatenated sequences of conservative genes, show that the Klebsiella phage KPPK108.1 belongs to the genus Drulisvirus, subfamily Slopekvirinae, family Autographiviridae. Intergenomic comparisons support this finding. Minor differences in genome organization can be explained by the recombination events that took place during the Klebsiella bacteriophages' evolution, as confirmed by the presence of NHN endonuclease genes in the genomes of KPPK108.1 and other related bacteriophages. The genome structure of the KPPK108.1 phage is typical for bacteriophages of the Autographivirinae family and is characterized by the presence of the early gene region [24], comprising gene 8 , encoding a hypothetical protein with an unusual L-shaped tertiary structure. Regardless of the fact that

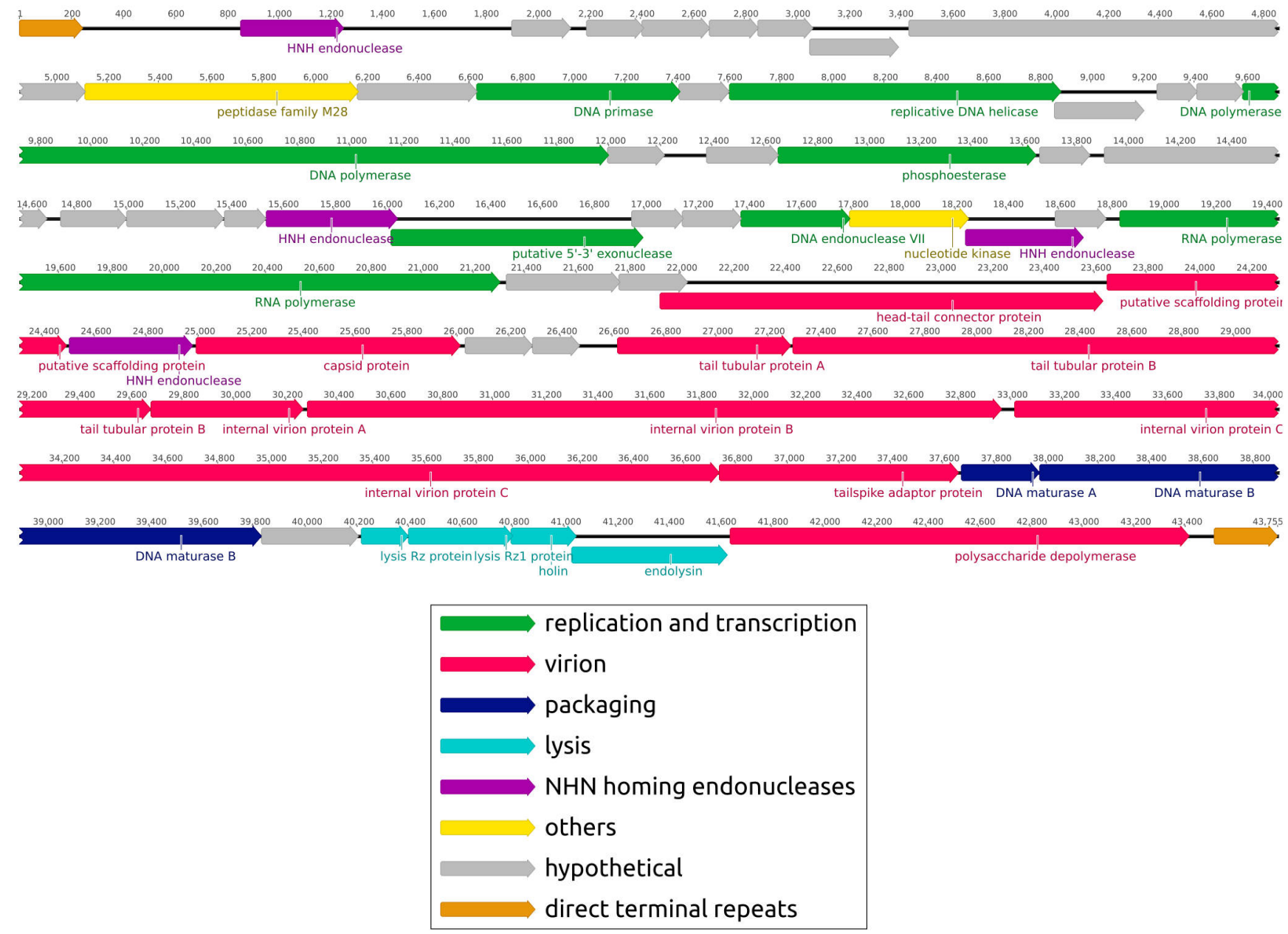

Fig. 2. Genetic map of Klebsiella bacteriophage KPPK108.1. Genes are colored in accordance with the functions of their products (see caption). Arrows indicate gene directions in accordance with their encoding functions 

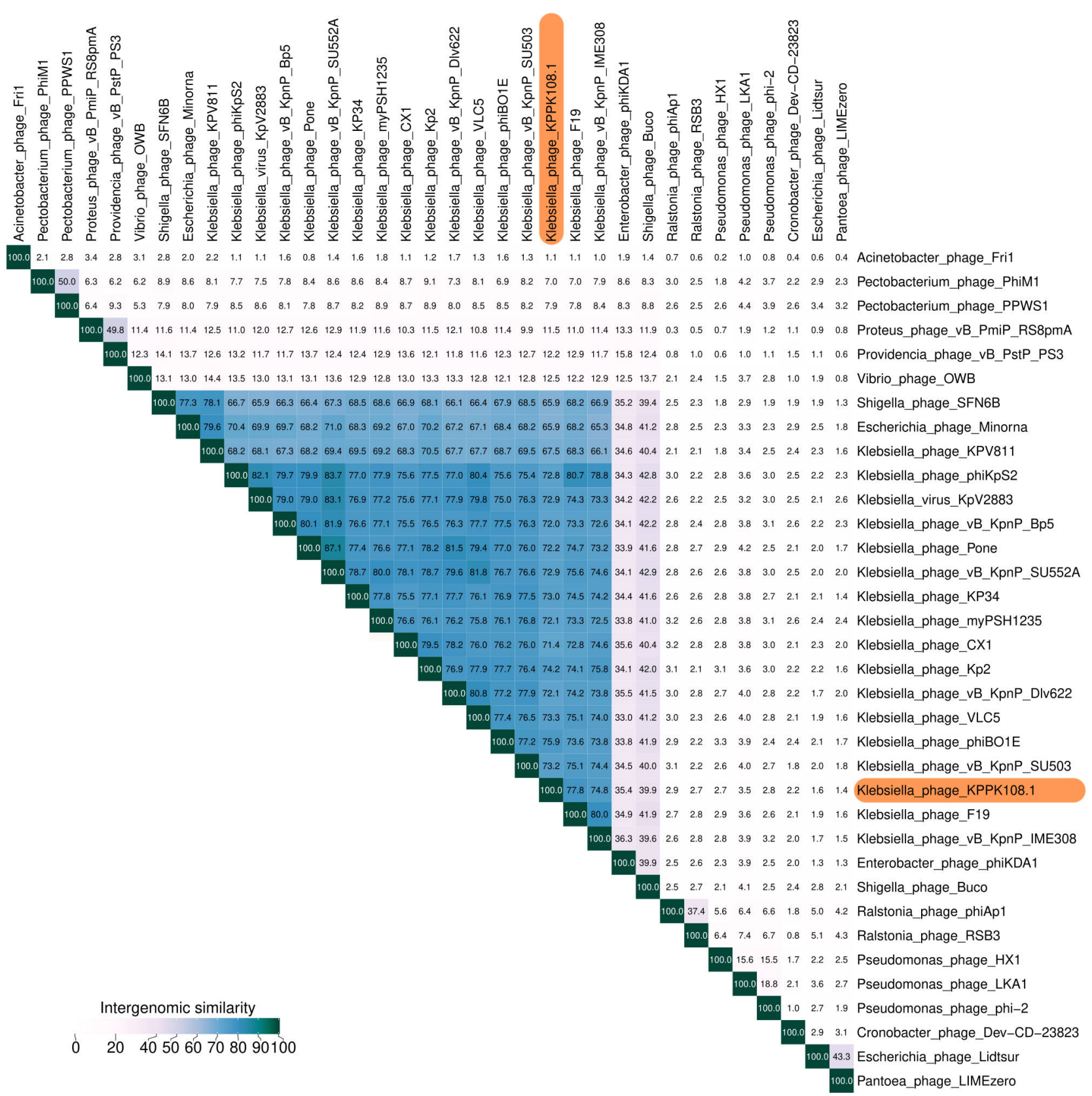

Fig. 3. Average nucleotide identity (ANI) distance matrix of the Klebsiella phage KPPK108.1 generated with the VIRIDIC web-based tool using the genomes of various Autographiviridae family members

the function of this protein has not been defined by searching for homologues using BLAST, or searching for similar proteins by HMM-HMM comparison, the surface charge distribution makes it possible to assume that this protein mimics nucleic acid, like Ocr proteins, which are also located within the early gene regions in the genomes of other Autographiviridae, and are capable of DNA mimicking [25, 26]. It has been shown that Ocr protein effectively inhibits the BREX restriction modification system, facilitating phage infection [27].

Bioinformatic analysis of the KPPK108.1 phage genome makes it possible to predict the organizational structure of the adsorption apparatus comprised of the head-tail connector and the tailspike protein, possessing enzymatic properties. The tailspike protein seems to be the receptor-binding protein (RBP), which determines host specificity and the host spectrum of the phage [28]. The tailspike protein structure analysis indicates the presence of depolymerizing activity against the polysaccharide, presumed to be related to the E. coli colanic acid. Colanic acid, the extracellular polysaccharide, consisting of several types of carbohydrate residues (such as L-fucose, D-glucose, D-galactose, and D-glucuronic acid), which is released into the extracellular environment by bacteria of the Enterobacteriaceae family, is the colanidase substrate [29]. Colanidases have been relatively recently discovered in phage RBPs [30]. Colanidases are present in a number of virulent bacteriophages of the evolutionarily distant groups, such as podoviruses and myoviruses [23, 30], some of which have proven to be effective when used in phage cocktails for phage therapy [30]. It is essential to define the structure of the type K108 K. pneumoniae capsular polysaccharide to clarify the question of the similarity of this polymer to colanic acid.

\section{CONCLUSIONS}

Klebsiella bacteriophage KPPK108.1 is a virulent bacteriophage of the genus Drulisvirus, family Autographiviridae. Thorough 


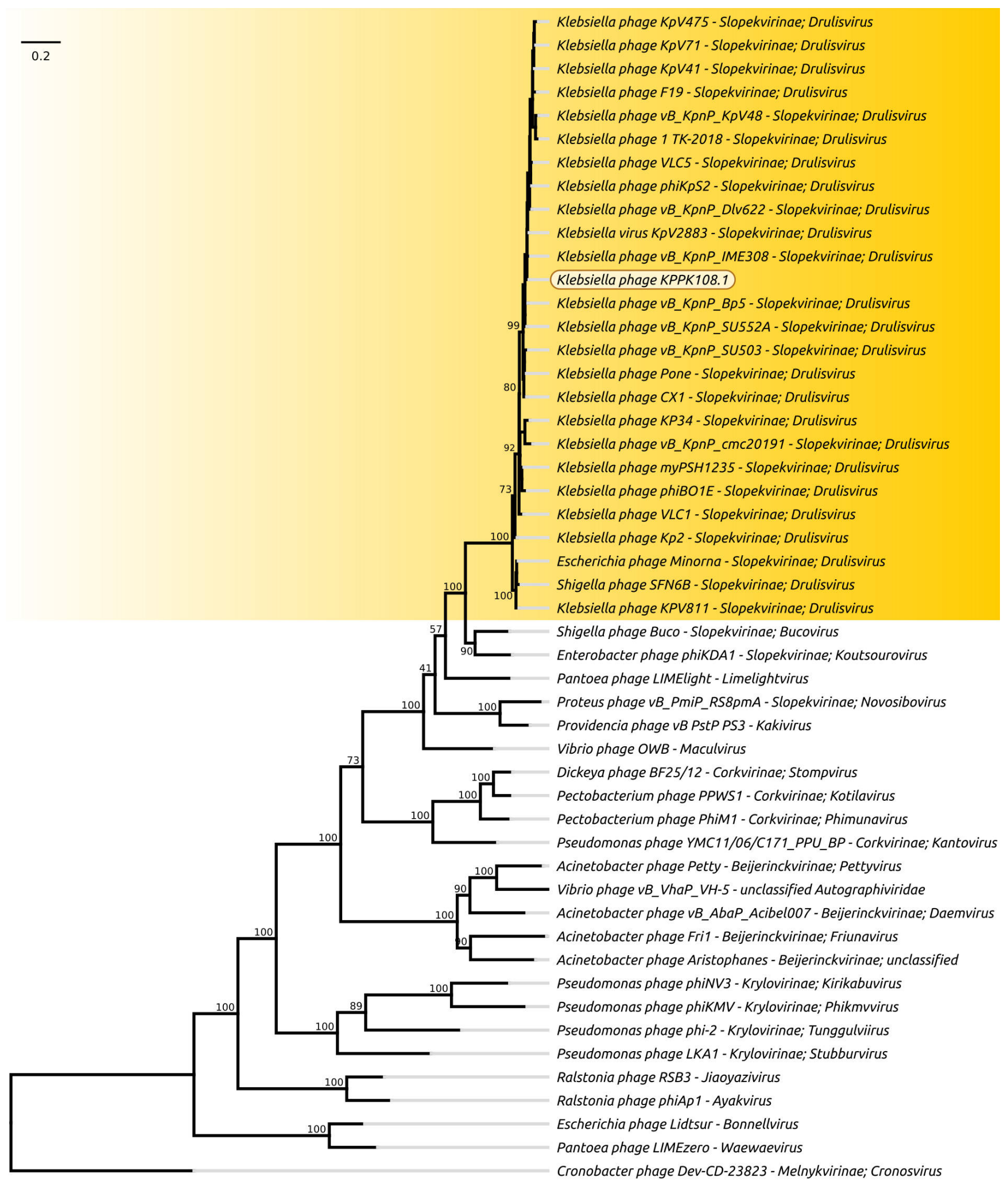

Fig. 4. Phylogenetic tree of Klebsiella phage KPPK108.1 and other Autographiviridae phages generated with the RaxML program using the concatenated amino acid sequences of the major capsid protein, terminase large subunit, DNA polymerase, and RNA polymerase

bioinformatic analysis has revealed the lytic nature of the phage infection cycle. The analysis makes it possible to predict the structure of the phage adsorption apparatus comprised of the head-tail connector and the tailspike protein, exhibiting colanidase activity. The predicted characteristics of KPPK108.1 bacteriophage indicate the feasibility of using KPPK108.1 in phage cocktails for phage therapy. As far as we know, KPPK108.1 is the first fully described phage specific for capsular type KL108. 


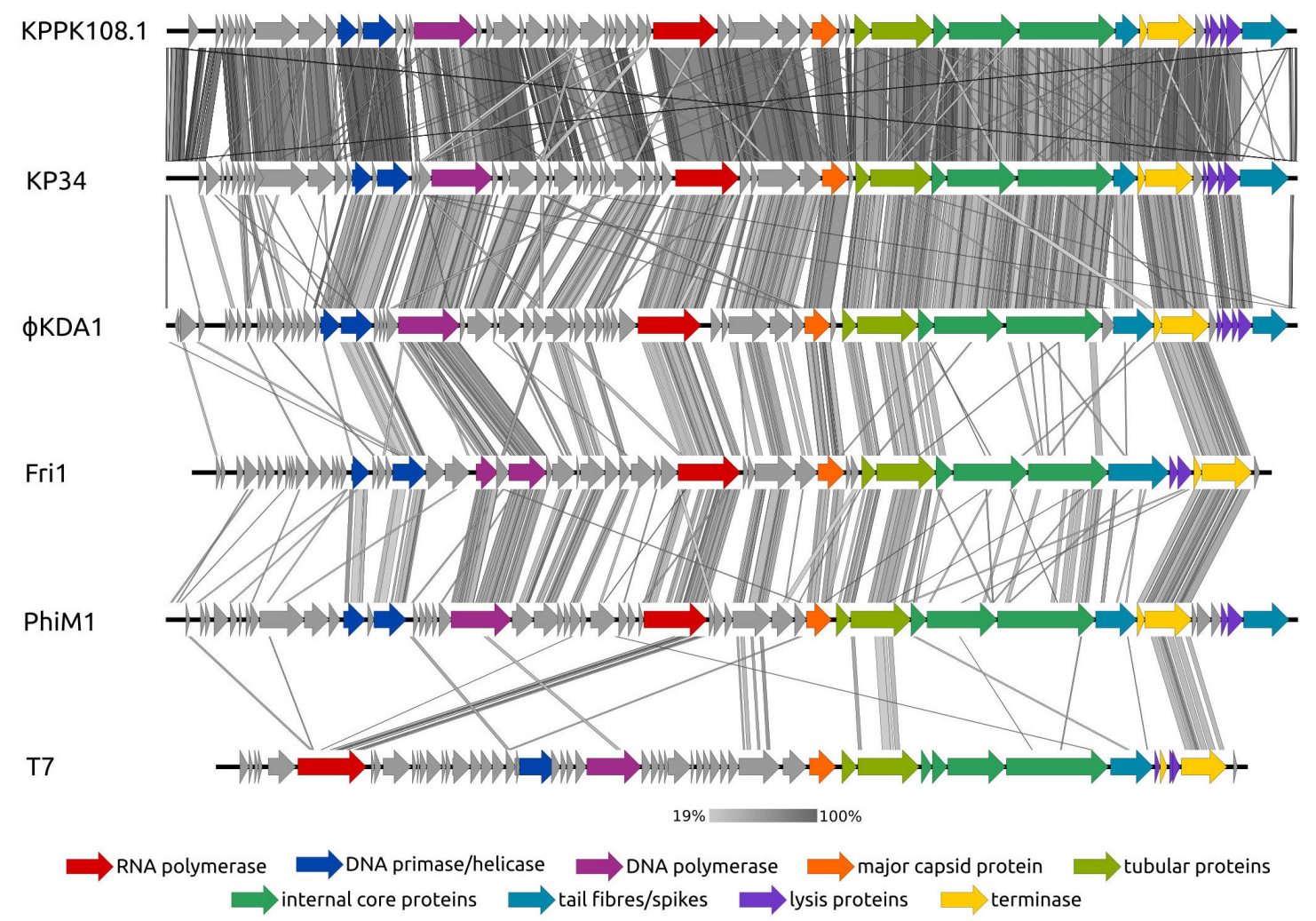

Fig. 5. Intergenomic comparison diagram created with EasyFig and TBLASTX using the genomes of Klebsiella phage KPPK108.1 and other Autographiviridae phages. The vertical lines are colored in accordance with the color scale showing the degree of similarity

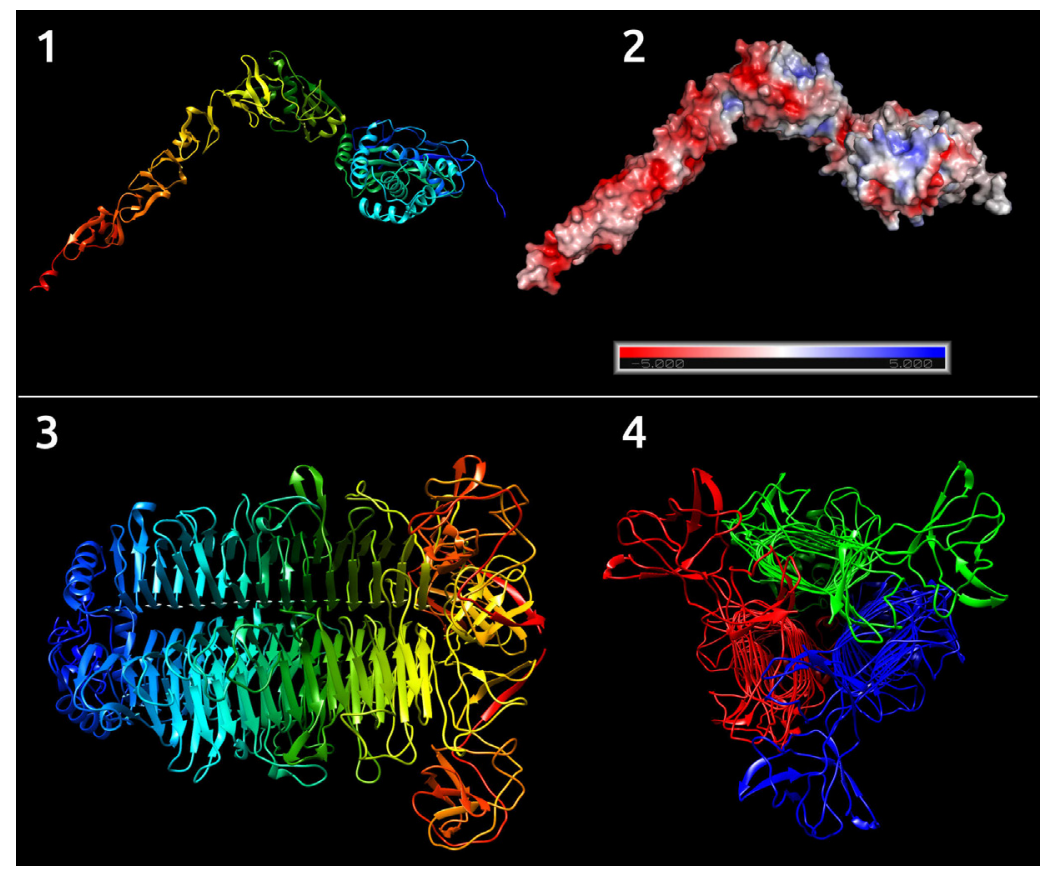

Fig. 6. Predicted tertiary structure of the KPPK108.1 phage gene 8 product painted with rainbow colors, where blue indicates N-terminal region, and red indicates C-terminal region of the protein (1). Predicted tertiary structure of the gene 8 product painted in accordance with the charge of the protein surface electrostatic field (2). Predicted tertiary structure of the KPPK108.1 phage tailspike trimer painted with rainbow colors, where blue indicates N-terminal region, and red indicates C-terminal region of the protein, longitudinal view (3). Predicted tertiary structure of the KPPK108.1 phage tailspike trimer with monomers painted with different colors, view along transverse axis (4) 


\section{References}

1. Paczosa MK, Mecsas J. Klebsiella pneumoniae: Going on the Offense with a Strong Defense. Microbiol Mol Biol Rev. 2016; 80 (3): 629-61.

2. Wyres KL, Wick RR, Gorrie C, Jenney A, Follador R, Thomson $\mathrm{NR}$, et al. Identification of Klebsiella capsule synthesis loci from whole genome data. Microb Genom. 2016; 2 (12): e000102.

3. Colombet J, Robin A, Lavie L, Bettarel Y, Cauchie HM, SimeNgando T. Virioplankton "pegylation": use of PEG (polyethylene glycol) to concentrate and purify viruses in pelagic ecosystems. J Microbiol Methods. 2007; 71 (3): 212-9.

4. Bankevich A, Nurk S, Antipov D, Gurevich AA, Dvorkin M, Kulikov AS, et al. SPAdes: a new genome assembly algorithm and its applications to single-cell sequencing. J Comput Biol. 2012; 19 (5): 455-77.

5. Drulis-Kawa Z, Mackiewicz P, Kęsik-Szeloch A, MaciaszczykDziubinska E, Weber-Dąbrowska B, Dorotkiewicz-Jach A, et al. Isolation and characterisation of KP34 - a novel $\varphi \mathrm{KMV}$ like bacteriophage for Klebsiella pneumoniae. Appl Microbiol Biotechnol. 2011; 90 (4): 1333-45.

6. Seemann T. Prokka: rapid prokaryotic genome annotation. Bioinformatics. 2014; 30 (14): 2068-9.

7. Altschul SF, Gish W, Miller W, Myers EW, Lipman DJ. Basic local alignment search tool. J Mol Biol. 1990; 215 (3): 403-10.

8. Gabler F, Nam S-Z, Till S, Mirdita M, Steinegger M, Söding J, et al Protein Sequence Analysis Using the MPI Bioinformatics Toolkit. Current Protocols in Bioinformatics. 2020; 72 (1): e108.

9. Kelley LA, Mezulis S, Yates CM, Wass MN, Sternberg MJE. The Phyre2 web portal for protein modeling, prediction and analysis. Nat Protoc. 2015; 10 (6): 845-58.

10. Geneious. Bioinformatics Software for Sequence Data Analysis. Geneious [cited 2021 Nov 11]. Available from: https://www. geneious.com/

11. Home - Genome - NCBI [cited 2021 Nov 11]. Available from: https://www.ncbi.nlm.nih.gov/genome.

12. Moraru C, Varsani A, Kropinski AM. VIRIDIC - A Novel Tool to Calculate the Intergenomic Similarities of Prokaryote-Infecting Viruses. Viruses. 2020; 12 (11): 1268.

13. Lee I, Ouk Kim Y, Park S-C, Chun J. OrthoANI: An improved algorithm and software for calculating average nucleotide identity. Int J Syst Evol Microbiol. 2016; 66 (2): 1100-3.

14. Stamatakis A. RAxML version 8: a tool for phylogenetic analysis and post-analysis of large phylogenies. Bioinformatics. 2014; 30 (9): 1312-3.

15. Le $S Q$, Gascuel O. An improved general amino acid replacement matrix. Mol Biol Evol. 2008; 25 (7): 1307-20.

16. Katoh K, Misawa K, Kuma K, Miyata T. MAFFT: a novel method for rapid multiple sequence alignment based on fast Fourier transform. Nucleic Acids Research. 2002; 30 (14): 3059-66.

17. Sullivan MJ, Petty NK, Beatson SA. Easyfig: a genome comparison

\section{Литература}

1. Paczosa MK, Mecsas J. Klebsiella pneumoniae: Going on the Offense with a Strong Defense. Microbiol Mol Biol Rev. 2016; 80 (3): 629-61.

2. Wyres KL, Wick RR, Gorrie C, Jenney A, Follador R, Thomson $N R$, et al. Identification of Klebsiella capsule synthesis loci from whole genome data. Microb Genom. 2016; 2 (12): e000102.

3. Colombet J, Robin A, Lavie L, Bettarel Y, Cauchie HM, SimeNgando T. Virioplankton "pegylation": use of PEG (polyethylene glycol) to concentrate and purify viruses in pelagic ecosystems. J Microbiol Methods. 2007; 71 (3): 212-9.

4. Bankevich A, Nurk S, Antipov D, Gurevich AA, Dvorkin M, Kulikov AS, et al. SPAdes: a new genome assembly algorithm and its applications to single-cell sequencing. J Comput Biol. 2012; 19 (5): 455-77.

5. Drulis-Kawa Z, Mackiewicz P, Kęsik-Szeloch A, MaciaszczykDziubinska E, Weber-Dąbrowska B, Dorotkiewicz-Jach A, et al. Isolation and characterisation of KP34 - a novel $\varphi$ KMV- visualizer. Bioinformatics. 2011; 27 (7): 1009-10.

18. Jumper J, Evans R, Pritzel A, Green T, Figurnov M, Ronneberger O, et al. Highly accurate protein structure prediction with AlphaFold. Nature. 2021; 596 (7873): 583-9.

19. Evans R, O'Neill M, Pritzel A, Antropova N, Senior A, Green T, et al. Protein complex prediction with AlphaFold-Multimer. 2021 [cited 2021 Dec 6]. 2021.10.04.463034. Available from: https:// www.biorxiv.org/content/10.1101/2021.10.04.463034v1.

20. Berman HM, Westbrook J, Feng Z, Gilliland G, Bhat TN, Weissig $\mathrm{H}$, et al. The Protein Data Bank. Nucleic Acids Research. 2000; 28 (1): 235-42.

21. Jurrus E, Engel D, Star K, Monson K, Brandi J, Felberg LE, et al. Improvements to the APBS biomolecular solvation software suite. Protein Science. 2018; 27 (1): 112-28.

22. Pettersen EF, Goddard TD, Huang CC, Couch GS, Greenblatt DM, Meng EC, et al. UCSF Chimera--a visualization system for exploratory research and analysis. J Comput Chem. 2004; 25 (13): 1605-12.

23. Schwarzer D, Buettner FFR, Browning C, Nazarov S, Rabsch W, Bethe A, et al. A Multivalent Adsorption Apparatus Explains the Broad Host Range of Phage phi92: a Comprehensive Genomic and Structural Analysis. Journal of Virology. 2012; 86 (19): 10384-98.

24. Evseev PV, Lukianova AA, Shneider MM, Korzhenkov AA, Bugaeva EN, Kabanova AP, et al. Origin and Evolution of Studiervirinae Bacteriophages Infecting Pectobacterium: Horizontal Transfer Assists Adaptation to New Niches. Microorganisms. 2020; 8 (11): 1707.

25. Roberts GA, Stephanou AS, Kanwar N, Dawson A, Cooper LP, Chen $\mathrm{K}$, et al. Exploring the DNA mimicry of the Ocr protein of phage T7. Nucleic Acids Res. 2012; 40 (16): 8129-43.

26. Zavilgelsky GB, Rastorguev SM. Antirestriction proteins ArdA and Ocr as efficient inhibitors of type I restriction-modification enzymes. Mol Biol. 2009; 43 (2): 241.

27. Isaev A, Drobiazko A, Sierro N, Gordeeva J, Yosef I, Qimron U, et al. Phage T7 DNA mimic protein Ocr is a potent inhibitor of BREX defence. Nucleic Acids Res. 2020; 48 (10): 5397-406.

28. Zampara A, Sørensen MCH, Grimon D, Antenucci F, Vitt AR, Bortolaia $\mathrm{V}$, et al. Exploiting phage receptor binding proteins to enable endolysins to kill Gram-negative bacteria. Sci Rep. 2020; 10 (1): 12087

29. Stevenson G, Andrianopoulos K, Hobbs M, Reeves PR. Organization of the Escherichia coli K-12 gene cluster responsible for production of the extracellular polysaccharide colanic acid. J Bacteriol. 1996; 178 (16): 4885-93.

30. Kim H, Kim M, Bai J, Lim J-A, Heu S, Ryu S. Colanic Acid Is a Novel Phage Receptor of Pectobacterium carotovorum subsp. carotovorum Phage POP72. Frontiers in Microbiology. 2019; 10: 143.

like bacteriophage for Klebsiella pneumoniae. Appl Microbiol Biotechnol. 2011; 90 (4): 1333-45.

6. Seemann T. Prokka: rapid prokaryotic genome annotation. Bioinformatics. 2014; 30 (14): 2068-9.

7. Altschul SF, Gish W, Miller W, Myers EW, Lipman DJ. Basic local alignment search tool. J Mol Biol. 1990; 215 (3): 403-10.

8. Gabler F, Nam S-Z, Till S, Mirdita M, Steinegger M, Söding J, et al. Protein Sequence Analysis Using the MPI Bioinformatics Toolkit. Current Protocols in Bioinformatics. 2020; 72 (1): e108.

9. Kelley LA, Mezulis S, Yates CM, Wass MN, Sternberg MJE. The Phyre2 web portal for protein modeling, prediction and analysis. Nat Protoc. 2015; 10 (6): 845-58.

10. Geneious. Bioinformatics Software for Sequence Data Analysis. Geneious [cited 2021 Nov 11]. Available from: https://www. geneious.com/

11. Home - Genome - NCBI [cited 2021 Nov 11]. Available from: https://www.ncbi.nlm.nih.gov/genome. 
12. Moraru C, Varsani A, Kropinski AM. VIRIDIC - A Novel Tool to Calculate the Intergenomic Similarities of Prokaryote-Infecting Viruses. Viruses. 2020; 12 (11): 1268.

13. Lee I, Ouk Kim Y, Park S-C, Chun J. OrthoANI: An improved algorithm and software for calculating average nucleotide identity. Int J Syst Evol Microbiol. 2016; 66 (2): 1100-3.

14. Stamatakis A. RAxML version 8: a tool for phylogenetic analysis and post-analysis of large phylogenies. Bioinformatics. 2014; 30 (9): 1312-3

15. Le SQ, Gascuel O. An improved general amino acid replacement matrix. Mol Biol Evol. 2008; 25 (7): 1307-20

16. Katoh K, Misawa K, Kuma K, Miyata T. MAFFT: a novel method for rapid multiple sequence alignment based on fast Fourier transform. Nucleic Acids Research. 2002; 30 (14): 3059-66.

17. Sullivan MJ, Petty NK, Beatson SA. Easyfig: a genome comparison visualizer. Bioinformatics. 2011; 27 (7): 1009-10.

18. Jumper J, Evans R, Pritzel A, Green T, Figurnov M, Ronneberger O et al. Highly accurate protein structure prediction with AlphaFold. Nature. 2021; 596 (7873): 583-9.

19. Evans R, O'Neill M, Pritzel A, Antropova N, Senior A, Green T, et al. Protein complex prediction with AlphaFold-Multimer. 2021 [cited 2021 Dec 6]. 2021.10.04.463034. Available from: https:// www.biorxiv.org/content/10.1101/2021.10.04.463034v1.

20. Berman HM, Westbrook J, Feng Z, Gilliland G, Bhat TN, Weissig $\mathrm{H}$, et al. The Protein Data Bank. Nucleic Acids Research. 2000; 28 (1): 235-42.

21. Jurrus E, Engel D, Star K, Monson K, Brandi J, Felberg LE, et al. Improvements to the APBS biomolecular solvation software suite. Protein Science. 2018; 27 (1): 112-28.

22. Pettersen EF, Goddard TD, Huang CC, Couch GS, Greenblatt DM, Meng EC, et al. UCSF Chimera--a visualization system for exploratory research and analysis. J Comput Chem. 2004; 25
(13): 1605-12.

23. Schwarzer D, Buettner FFR, Browning C, Nazarov S, Rabsch W Bethe A, et al. A Multivalent Adsorption Apparatus Explains the Broad Host Range of Phage phi92: a Comprehensive Genomic and Structural Analysis. Journal of Virology. 2012; 86 (19): 10384-98.

24. Evseev PV, Lukianova AA, Shneider MM, Korzhenkov AA, Bugaeva EN, Kabanova AP, et al. Origin and Evolution of Studiervirinae Bacteriophages Infecting Pectobacterium: Horizontal Transfer Assists Adaptation to New Niches. Microorganisms. 2020; 8 (11): 1707.

25. Roberts GA, Stephanou AS, Kanwar N, Dawson A, Cooper LP, Chen $\mathrm{K}$, et al. Exploring the DNA mimicry of the Ocr protein of phage T7. Nucleic Acids Res. 2012; 40 (16): 8129-43.

26. Zavilgelsky GB, Rastorguev SM. Antirestriction proteins ArdA and $\mathrm{Ocr}$ as efficient inhibitors of type I restriction-modification enzymes. Mol Biol. 2009; 43 (2): 241.

27. Isaev A, Drobiazko A, Sierro N, Gordeeva J, Yosef I, Qimron U, et al. Phage T7 DNA mimic protein Ocr is a potent inhibitor of BREX defence. Nucleic Acids Res. 2020; 48 (10): 5397-406.

28. Zampara A, Sørensen MCH, Grimon D, Antenucci F, Vitt AR, Bortolaia V, et al. Exploiting phage receptor binding proteins to enable endolysins to kill Gram-negative bacteria. Sci Rep. 2020; 10 (1): 12087

29. Stevenson G, Andrianopoulos K, Hobbs M, Reeves PR. Organization of the Escherichia coli K-12 gene cluster responsible for production of the extracellular polysaccharide colanic acid. J Bacteriol. 1996; 178 (16): 4885-93.

30. Kim H, Kim M, Bai J, Lim J-A, Heu S, Ryu S. Colanic Acid Is a Novel Phage Receptor of Pectobacterium carotovorum subsp. carotovorum Phage POP72. Frontiers in Microbiology. 2019; 10: 143. 